\title{
Quality of life in Type 1 (insulin-dependent) diabetic patients prior to and after pancreas and kidney transplantation in relation to organ function
}

\author{
W. Piehlmeier ${ }^{1}$, M. Bullinger ${ }^{3}$, J. Nusser ${ }^{1}$, A. König ${ }^{1}$, W.-D. Illner ${ }^{2}$, D. Abendroth ${ }^{2}$, W. Land ${ }^{2}$ and R. Landgraf $^{1}$ \\ ${ }^{1}$ Department of Internal Medicine "Innenstadt", ${ }^{2}$ Transplantation Center, ${ }^{3}$ Institute for Medical Psychology, University of Munich, \\ Munich, FRG
}

Summary. Improvement of the quality of life in Type 1 (insulin-dependent) diabetic patients with severe late complications is one of the main goals of pancreas and/or kidney grafting. To assess the influences of these treatment modalities on the different aspects of the quality of life a cross-sectional study in 157 patients was conducted. They were categorized into patients pretransplant without dialysis $(n=29$; Group $A)$, pretransplant under dialysis ( $n=44$; Group $B)$, posttransplant with pancreas and kidney functioning $(n=31$; Group C), post-transplant with functioning kidney, but insulin therapy ( $n=29$; Group $D)$, post-transplant under dialysis and insulin therapy again ( $n=15$; Group $E$ ) and patients after single pancreas transplantation and rejection, with good renal function, but insulin therapy $(n=9$; Group F). All patients answered a mailed, selfadministered questionnaire (217 questions) consisting of a broad spectrum of rehabilitation criteria. The results indicate a better quality of life in Groups $C$ and $D$ as compared to the other groups. In general the scores are highest in $C$, but without any significant difference to $D$. Impressive significant differences between $C$ or $D$ and the other groups were found especially in their satisfaction with physical capacity, leisure-time activities or the overall quality of life. The satisfaction with the latter is highest in $C$ (mean \pm SEM: $4.0 \pm 0.2$ on a 1 to 5 - rating scale; significantly different from A: $3.1 \pm 0.1$, B: $2.7 \pm$ 0.2 and $E: 2.6 \pm 0.3 ; p<0.01)$, followed by $D(3.8 \pm$ 0.2 ; significantly different from $\mathrm{B}$ and $\mathrm{E} ; \mathrm{p}<0.01$ ). Group $F$ shows a mean of $3.1 \pm 0.4$, which is not significantly different from $\mathrm{C}$. The percentages of patients in each group, who are not working: A: $38 \%, \mathrm{~B}: 64 \%$, C: $74 \%$, D: $66 \%$, E: $87 \%$ and F: $78 \%$ indicate that there is no marked improvement in the vocational situation after successful grafting.

Key words: Diabetes mellitus - Pancreas transplantation - Kidney transplantation - Quality of life - Rehabilitation

\section{Introduction}

Quality of life assessment is important not only with regard to medical but also in socio-economic aspects. This is true especially for expensive and incisive therapeutic regimens which aim to prolong life (Najman \& Levine 1981). In surgery there is a trend towards measuring physical and psychosocial effects of interventions (WoodDauphinee \& Troidl 1986; O’Young \& McPeek 1987; Troidl et al. 1987; Wood-Dauphinee \& Troidl 1989; Koostra in press; Neugebauer et al. in press) and this has recently also been voiced with respect to transplantation (Kaplan De-Nour \& Shanan 1980; Evans et al. 1985; Andrykowski et al. 1987; Hart \& Evans 1987; Nakache et al. 1989; Vorugati \& Sells 1989; Muthny et al. 1990; Corry \& Zehr 1990; Johnson et al. 1990; Bullinger et al. 1991; Kemkes in press). So far there is little information as to how pancreatic grafting affects the quality of life in patients with longstanding diabetes. Preliminary data (Nakache et al. 1989; Vorugati \& Sells 1989; Corry \& Zehr 1990; Johnson et al. 1990) and clinical experiences from many centres suggest however that pancreas transplantation can improve many aspects of the physical and psychosocial well-being of diabetic individuals with severe secondary complications. There is some disagreement on how to measure quality of life (Derogatis 1975; Guyatt et al. 1986; Bremer \& McCauley 1986; Leighton et al. 1987; McDowell \& Newell 1987; Wood-Dauphinee \& Williams 1987; Patrick \& Erickson 1988; Walker \& Rosser 1988; Aaronson 1989; Bullinger 1989; Bullinger in press). Some authors prefer structured inpatient interviews, some an evaluation by the physician, and others use home-based questionnaires. Using a mailed self-administered questionnaire this study describes for the first time a detailed cross-sectional analysis of the quality of life of patients after successful kidney and/or pancreas transplantation compared with diabetic subjects with or without dialysis treatment prior to transplantation, patients after failure of the kidney, the pancreas or both organs. 


\section{Subjects and methods}

Subjects. The patient sample consisted of 157 Type 1 (insulindependent) diabetic subjects with severe late complications, who had either received a pancreas and/or kidney transplantation between 1979 and 1989 or were on the waiting list for transplantation. Important data of the patients analyzed are listed in detail in Table 1. There were no statistical significant differences between the groups except for a younger age of group $F$ patients.

Methods. The study was designed as a cross-sectional analysis using a patient-based questionnaire, which is a modified version of an instrument previously administered to renal transplant recipients (Muthny et al. 1990). It contains 6 relevant components of quality of

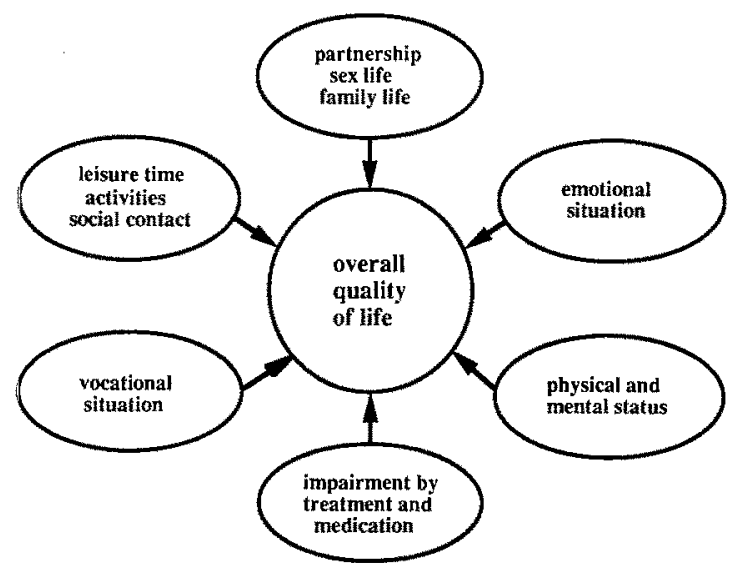

Fig.1. Main components of the overall quality of life, which have been considered in this study life (Fig.1), consisting of 217 questions, most of them to be rated with a score system from 1 to 5 , representing for example "very dissatisfied" (1), "dissatisfied" (2), "neither-nor" (3), "satisfied" (4) or "very satisfied" (5). Additionally 59 questions on somatic complaints potentially present in type 1 diabetics with a long duration of their disease and secondary complications were introduced. Fifteen sum scores conceming physical and emotional situation or leisure-time activities were calculated, which have been tested for intemal consistency (Cronbach's alpha). For evaluation of the emotional situation two of the nine SCL-90-R subscales, anxiety (10 items) and depression (13 items), all items rated from 1 ( not at all ) to 5 ( very strong ) were applied, additionally both a positive and a negative emotions scale. Since some patients left questions uncompleted, sum score values were divided by the number of answered items provided that more than $70 \%$ of the items had been filled in. Moreover open questions for the patients' coping with their pre- or postoperative situation and on socio-economic aspects like age, sex, number of children, education or vocational situation were included.

Statistical analysis. All data are presented as mean \pm SEM for scales or frequencies for questions. For statistical analysis of intergroup differences the Student's t-test with Bonferroni adjustment for multiple testing was used. Relationships between the different subscales and the overall quality of life were analyzed via Spearman correlation coefficients. Multiple regression analysis was used to determine the variables contributing most strongly to the overall quality of life.

\section{Results \\ Leisure-time activities and social contact}

The means for the satisfaction with leisure-time activities and number of friends for all groups are presented in Figure 2. There were significant differences between

Table 1. Clinical data of the patient sample consisting of 157 Type 1 (insulin-dependent) diabetic subjects

\begin{tabular}{|c|c|c|c|c|c|c|}
\hline Group & & $\begin{array}{l}\text { Sex } \\
(f / m)\end{array}$ & $\underset{\text { (years) }}{\text { Age }^{\mathbf{x}}}$ & $\begin{array}{l}\text { Duration } \\
\text { of diabetes } \\
\text { (years) }\end{array}$ & $\begin{array}{l}\text { Time on } \\
\text { dialysis } \\
\text { pretransplant } \\
\text { (months) }\end{array}$ & $\begin{array}{l}\text { Time since } \\
\text { transplantation } \\
\text { (months) }\end{array}$ \\
\hline $\begin{array}{c}A \\
(n=29)\end{array}$ & $\begin{array}{l}\text { Pre-transplant } \\
\text { without dialysis }\end{array}$ & $14 / 15$ & $\begin{array}{l}32.7 \pm 1.3 \\
21-55\end{array}$ & $\begin{array}{l}22.7 \pm 1.2 \\
11.2-43.3\end{array}$ & - & - \\
\hline $\begin{array}{c}B \\
(n=44)\end{array}$ & $\begin{array}{l}\text { Pre-transplant } \\
\text { under dialysis }\end{array}$ & $17 / 27$ & $\begin{array}{l}35.2 \pm 1.2 \\
19-51\end{array}$ & $\begin{array}{l}22.1 \pm 1.0 \\
4.6-38.5\end{array}$ & $\begin{array}{l}28.8 \pm 3.1 \\
7-117\end{array}$ & - \\
\hline$\underset{(n=31)}{C}$ & $\begin{array}{l}\text { Post-transplant, } \\
\text { pancreas and kidney } \\
\text { functioning }\end{array}$ & $17 / 14$ & $\begin{array}{l}38.4 \pm 1.6 \\
26-55\end{array}$ & $\begin{array}{l}26.6 \pm 1.1 \\
17.9 \cdot 41.1\end{array}$ & $\begin{array}{l}24.8 \pm 3.5 \\
2-100\end{array}$ & $\begin{array}{l}27.0 \pm 4.3 \\
2-87\end{array}$ \\
\hline$\underset{(n=29)}{D}$ & $\begin{array}{l}\text { Post-transplant, } \\
\text { kidney functioning, } \\
\text { insulin therapy }\end{array}$ & $18 / 11$ & $\begin{array}{l}37.2 \pm 1.4 \\
23-55\end{array}$ & $\begin{array}{l}25.3 \pm 1.6 \\
12.8-49.1\end{array}$ & $\begin{array}{l}29.4 \pm 5.5 \\
2 \cdot 126\end{array}$ & $\begin{array}{l}33.7 \pm 4.0 \\
1-91\end{array}$ \\
\hline$\underset{(n=15)}{E}$ & $\begin{array}{l}\text { Post-transplant, } \\
\text { under dialysis and } \\
\text { insulin therapy }\end{array}$ & $7 / 8$ & $\begin{array}{l}38.6 \pm 2.1 \\
28-52\end{array}$ & $\begin{array}{l}27.2 \pm 1.6 \\
18.2-37.7\end{array}$ & $\begin{array}{l}24.3 \pm 5.9 \\
2-84\end{array}$ & $\begin{array}{l}43.1 \pm 7.6 \\
7-100\end{array}$ \\
\hline $\begin{array}{c}F \\
(n=9)\end{array}$ & $\begin{array}{l}\text { After single pancreas } \\
\text { grafting and rejection, } \\
\text { own kidney functioning }\end{array}$ & $6 / 3$ & $\begin{array}{l}28.1 \pm 1.6 \\
22-38\end{array}$ & $\begin{array}{l}22.7 \pm 1.6 \\
14.3-30.1\end{array}$ & - & $\begin{array}{l}27.1 \pm 6.7 \\
6-64\end{array}$ \\
\hline
\end{tabular}

$x \quad$ numbers represent mean, SEM and range

a patients in group $F$ significantly $(p<0.05)$ younger than in groups $C, D$ and $E$ 
groups $\mathrm{C}$ (significantly different from $\mathrm{B} ; \mathrm{p}<0.01$ and $\mathrm{E}$; $p<0.05$ ) or D (significantly different from $B ; p<0.05$ ) and the other groups with respect to their satisfaction with leisure time activities. High percentages in groups $\mathrm{C}$ $(55 \%)$ and D (55\%) were "satisfied" and "very satisfied" with these activities in contrast to the other groups ( 20 to $32 \%$ ). More patients in group C $(74 \%)$ and D $(72 \%)$ were "satisfied" or "very satisfied" with the number of friends compared to the other groups (ranging from 45 to $62 \%$ ). Transplantation-related changes in recreational activities are listed in Table 2.

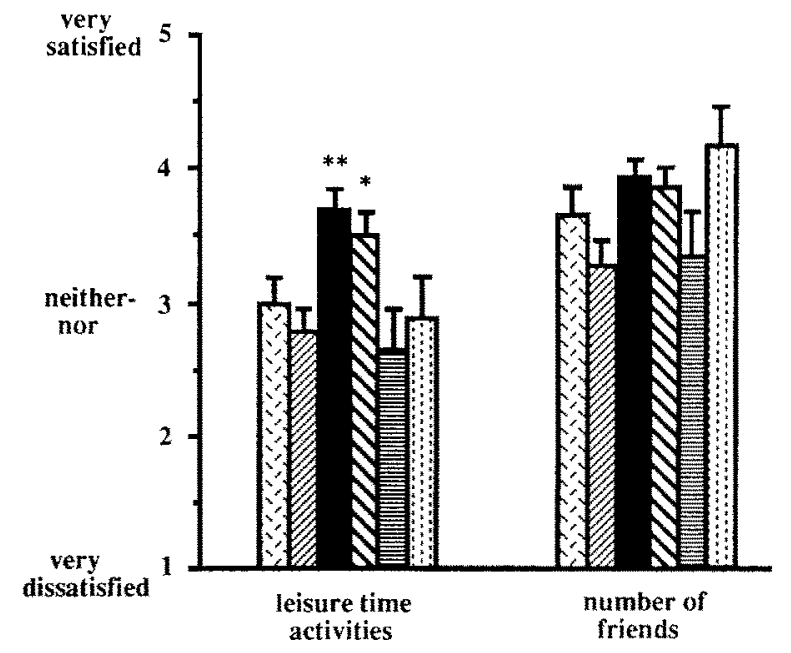

Fig.2. Mean scores of different patient groups concerning satisfaction with leisure-time activities and number of friends. The six score columns per question represent from left to right 0 Group A: pre-transplant without dialysis, Group B: pre-transplant under dialysis, Group C: post-transplant, pancreas and kidney functioning, Group D: post-transplant, kidney functioning, but insulin therapy, 国 Group E: post-transplant under dialysis and insulin therapy and 7 Group F: after single pancreas grafting and rejection, own kidney functioning. ${ }^{*} \mathrm{p}<0.05 ;{ }^{* *} \mathrm{p}<0.01$

Table 2. Percentages of the patients in each post-transplant group giving the answers "more" and "much more" for changes in the following aspects of leisure-time activities from the pre- to the posttransplant period. For further details see legend to Figure 2.

\begin{tabular}{lcccc}
\hline Group & C & D & E & F \\
\hline Holidays & 35 & 52 & 7 & 33 \\
Sports & 52 & 41 & 13 & 11 \\
Cultural life & 32 & 52 & 0 & 0 \\
$\begin{array}{l}\text { Being among } \\
\text { people }\end{array}$ & 74 & 59 & 13 & 11 \\
$\begin{array}{l}\text { Hobbies } \\
\text { Hobies }\end{array}$ & 45 & 38 & 13 & 0 \\
\hline
\end{tabular}

\section{Vocational situation}

The mean scores of satisfaction with the vocational situation (Fig.3) are highest in $C$ (significantly different from $B ; p<0.01$ ), followed by A (significantly different from $B ; p<0.05$ ) and $D$. The lowest scores were seen in patients on dialysis awaiting transplantation. The satisfaction with the financial situation is very similar in $A, C$ and $D$, without any significant difference to the lower scores in the other groups. When analyzing the more detailed information given by the patient, the vocational situation seems not to improve substantially after successful transplantation (Table 3). Asked for the reasons for not working, mainly the present health status (even in C and D), fears about medical complications, other tasks like taking care for the family or simply the satisfaction with the disability pension $(26 \%$ in C) were given. Less important were problems in connection with the general job situation. The actual rate of unemployment in Germany is 8-15\%.

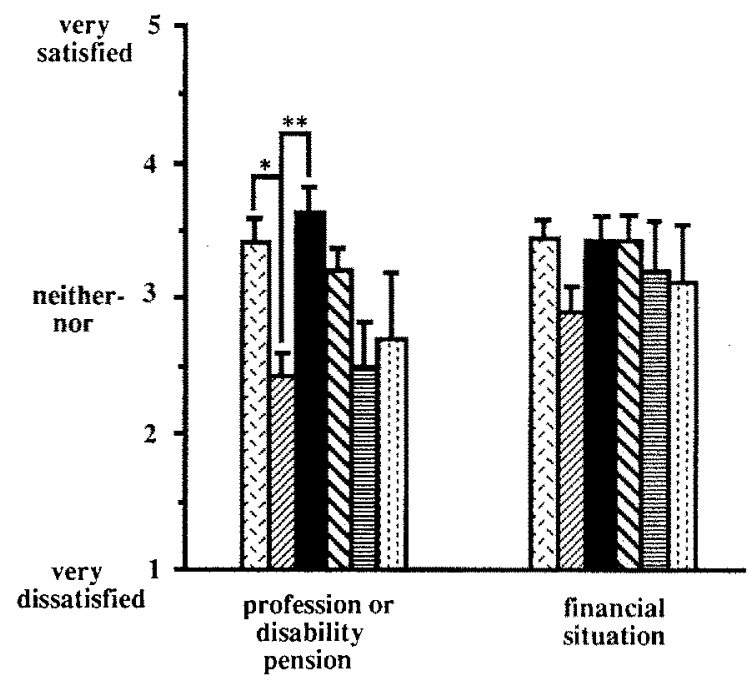

Fig.3. Mean scores of satisfaction with vocational and financial situation. For further details see legend to Figure 2. ${ }^{*} \mathrm{p}<0.05 ; * *<0.01$

Table 3. Vocational situation in the different groups (percentages of the patients in each group). For details see legend to Figure 2 .

\begin{tabular}{lcccccc}
\hline Group & A & B & C & D & E & F \\
\hline $\begin{array}{l}\text { Not } \\
\text { working }\end{array}$ & 38 & 64 & 74 & 66 & 87 & 78 \\
$\begin{array}{l}\text { Disability } \\
\text { pension }\end{array}$ & 24 & 48 & 68 & 55 & 53 & 33 \\
$\begin{array}{l}\text { Scholar } / \\
\text { student }\end{array}$ & 10 & 9 & 3 & 0 & 0 & 22 \\
\hline
\end{tabular}

\section{Partnership, sexual and family life}

The satisfaction with partnership and family life were highest in C, followed by $D$, but also comparatively high in the other groups without significant differences between the groups (Fig.4). Satisfaction with sexual activity is highest in $\mathrm{D}$ and significantly different only to $\mathrm{B}$ $(p<0.05)$. More information about interpersonal relationships is given in Table 4. 


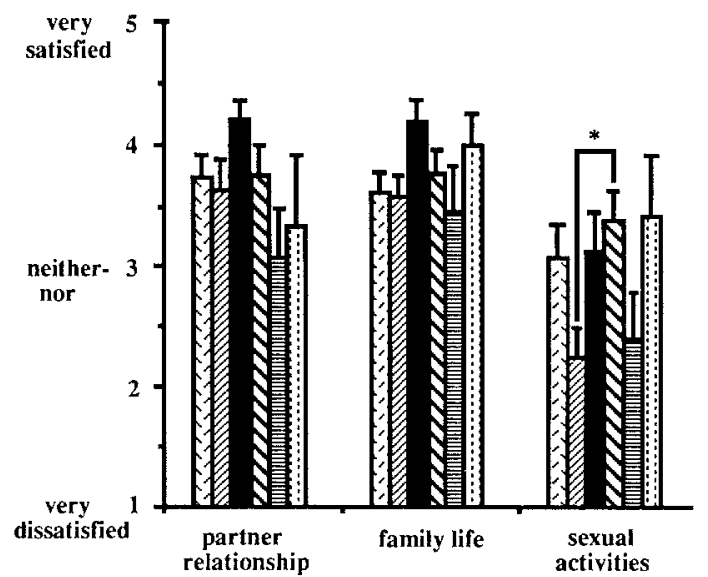

Fig.4. Mean scores of satisfaction with partner relationship, family life and sexual activities. For further details see legend to Figure $2 .{ }^{*} \mathrm{p}<0.05 ;{ }^{* *} \mathrm{p}<0.01$

Table 4. Social support and sexuality in the different groups ( percentages of the patients in each group). See legend to Figure 2 .

\begin{tabular}{|c|c|c|c|c|c|c|}
\hline Group & A & B & C & $\mathrm{D}$ & E & $\mathrm{F}$ \\
\hline $\begin{array}{l}\text { Living } \\
\text { together } \\
\text { with others }\end{array}$ & 69 & 75 & 84 & 69 & 80 & 44 \\
\hline $\begin{array}{l}\text { Stable } \\
\text { partnership }\end{array}$ & 66 & 50 & 81 & 69 & 60 & 44 \\
\hline Married & 52 & 52 & 74 & 62 & 60 & 22 \\
\hline $\begin{array}{l}\text { No sexual } \\
\text { activity } \\
\text { during last } \\
\text { month }\end{array}$ & 24 & 48 & 32 & 24 & 40 & 22 \\
\hline
\end{tabular}

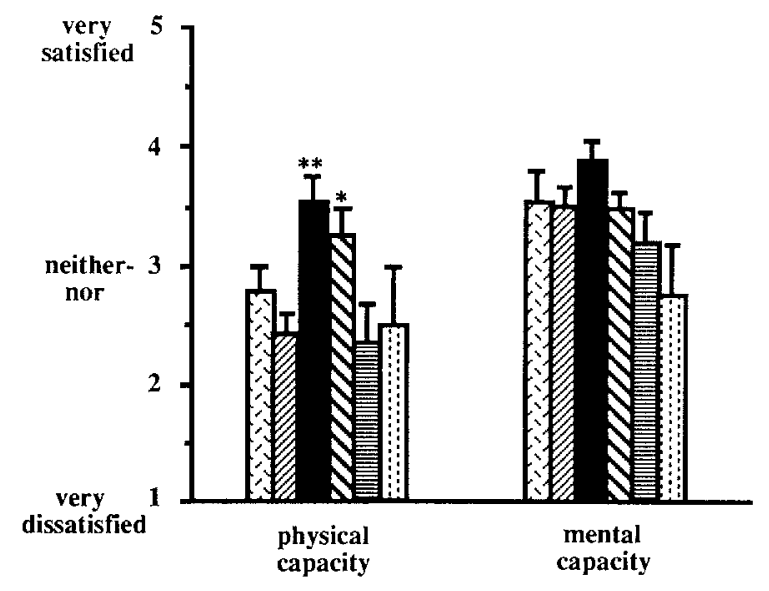

Fig.5. Mean scores of satisfaction with physical and mental status. For details see legend to Figure $2 ;{ }^{*} p<0.05 ;{ }^{* *} p<0.01$

\section{Physical and mental status}

The satisfaction with the physical capacity was highest in $C$ and differed significantly from $B(p<0.01)$ and $E$ ( $p<0.05$ ). It is followed by $D$, which was significantly different from $B(p<0.05$; Fig. 5). However, when asked about a reduced physical capacity, many patients in $\mathrm{C}$ and $\mathrm{D}$ also feel impaired (79 \% in A, $82 \%$ in B, $58 \%$ in C, $66 \%$ in $\mathrm{D}, 87 \%$ in $\mathrm{E}$ and $44 \%$ in F). While all groups were comparable in their problems with wound healing (intergroup range 55 to $64 \%$ ), they showed differences especially in hypoglycaemic episodes (Table 6). Table 5 gives six sum scores concerning diabetic secondary complications. Only small differences appear across groups with the exception of primary diabetic symptoms (Group C significantly different from $B ; p<0.01$; see

Table 5. Means \pm SEM of all items belonging to the primary diabetic symptoms (9 items), the symptoms of angiopathy ( 9 items), peripheral neuropathy ( 9 items), autonomic neuropathy (12 items), nephropathy (11 items) and retinopathy ( 2 items). These different item lists have been tested for internal consistency using the Crohnbach's alpha coefficient (mentioned below).

\begin{tabular}{|c|c|c|c|c|c|c|}
\hline Group & A & B & $\mathrm{C}$ & $\mathrm{D}$ & $\mathrm{E}$ & $\mathbf{F}$ \\
\hline $\begin{array}{l}\text { Primary diabetic } \\
\text { symptoms } \\
(\text { alpha }=0.68)\end{array}$ & $2.0 \pm 0.11$ & $2.4 \pm 0.07$ & $1.8 \pm 0.12$ & $2.1 \pm 0.14$ & $2.3 \pm 0.23$ & $2.3 \pm 0.26$ \\
\hline $\begin{array}{l}\text { Angiopathy } \\
\text { symptoms } \\
(\text { alpha }=0.62)\end{array}$ & $1.5 \pm 0.08$ & $1.6 \pm 0.07$ & $1.4 \pm 0.08$ & $1.5 \pm 0.08$ & $1.7 \pm 0.22$ & $1.6 \pm 0.17$ \\
\hline $\begin{array}{l}\text { Peripheral } \\
\text { neuropathy } \\
\text { symptoms } \\
(\text { alpha }=0.88)\end{array}$ & $1.8 \pm 0.13$ & $2.3 \pm 0.15$ & $1.7 \pm 0.12$ & $1.9 \pm 0.16$ & $2.0 \pm 0.28$ & $2.1 \pm 0.40$ \\
\hline $\begin{array}{l}\text { Autonomic } \\
\text { neuropathy } \\
\text { symptoms } \\
(\text { alpha }=0.80)\end{array}$ & $1.8 \pm 0.10$ & $1.9 \pm 0.10$ & $1.8 \pm 0.10$ & $1.7 \pm 0.09$ & $1.8 \pm 0.25$ & $2.2 \pm 0.25$ \\
\hline $\begin{array}{l}\text { Nephropathy } \\
\text { symptoms } \\
(\text { alpha }=0.86 \text { ) }\end{array}$ & $1.5 \pm 0.09$ & $2.3 \pm 0.11$ & $2.1 \pm 0.14$ & $2.2 \pm 0.13$ & $2.4 \pm 0.24$ & $1.7 \pm 0.35$ \\
\hline Retinopathy & $3.2 \pm 0.23$ & $3.0 \pm 0.19$ & $2.4 \pm 0.22$ & $2.7 \pm 0.31$ & $2.8 \pm 0.37$ & $3.7 \pm 0.50$ \\
\hline
\end{tabular}

a group B significant different from $C ; p<0.01$ 
also Table 6) and retinopathy symptoms (differences not significant). The satisfaction with mental capacity is best in $\mathrm{C}$, but not significantly different from the other groups (Fig. 5). Many patients in all groups have problems in concentrating or remembering (see again Table 6). The patients in Group F could not be analyzed for the last items because several answers were missing.

Table 6. Percentages of the patients in each group suffering from physical and mental symptoms. For details see legend to Figure 2.

\begin{tabular}{lcccccc}
\hline Group & A & B & C & D & E & F \\
\hline Polydipsia & 62 & 84 & 22 & 41 & 60 & 56 \\
$\begin{array}{l}\text { Hypo- } \\
\text { glycaemia }\end{array}$ & 83 & 75 & 29 & 83 & 73 & 89 \\
$\begin{array}{l}\text { Problems in } \\
\text { concentrating }\end{array}$ & 41 & 68 & 55 & 73 & 67 & - \\
$\begin{array}{l}\text { Problems in } \\
\text { remembering }\end{array}$ & 38 & 68 & 42 & 73 & 60 & - \\
\hline
\end{tabular}

\section{Impairment by treatment and medication}

Pre- and post-transplant dialysis patients (B and $E$ ) feel most impaired by regular visits to physicians (B significantly more than $A ; p<0.01$ ) and dietary restrictions. Group $\mathrm{C}$ also complains of the latter, probably due to body weight problems originating from continuous steroid medication and well-being. The differences between all groups concerning the fears of adverse drug side effects are neglegible (Fig.6). In Groups $\mathrm{C}$ and $\mathrm{D}$ the fears of drug side effects are mostly related to steroids and cyclosporine, in both dialysis groups to antihypertensive drugs. The percentages of post-transplant hospitalisation were $58 \%$ in $\mathrm{C}$, mostly because of rejection episodes, urinary tract infections and hypertension, $59 \%$ in D, mainly due to urinary tract

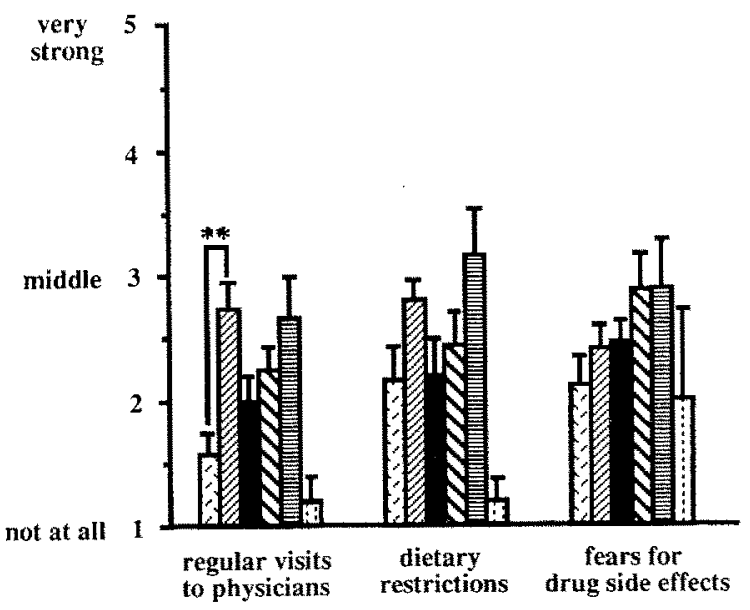

Fig.6. Mean scores of impaiment by regular visits to physicians, dietary restrictions and fears for adverse drug side effects. For further details see legend to Figure $2 .{ }^{*} \mathrm{p}<0.05 ;{ }^{* *} \mathrm{p}<0.01$ infections and rejection episodes, $87 \%$ in $\mathrm{E}$ and $66 \%$ in $F$, mostly because of rejection episodes. During the previous year $45 \%$ of patients in A stayed in hospital due to eye problems, gastrointestinal symptoms and insulin adaption problems. In the same period $61 \%$ of Group B patients needed hospital care, mostly because of insulin adaption difficulties, problems with angiopathy or hypertension, haemorrhages and gastrointestinal complaints.

\section{Emotional situation}

The mean scores of SCL-90-R anxiety and depression subscales are shown in Figure 7. Symptoms of anxiety are lower in C and D than in the other groups without reaching significance, symptoms of depression are lowest in $\mathrm{C}$ (significantly different from $\mathrm{B} ; \mathrm{p}<0.01$ ) followed by D. The mean scores of the positive emotions ( 7 items like optimism, energy or self consciousness) show the best emotional situation in $\mathrm{C}$ (significantly better than $\mathrm{E}$, $\mathrm{p}<0.01$ ). Asked about fears for rejection, $25 \%$ of group $\mathrm{C}$ patients report that these are "frequent" and "very frequent" ("sometimes" in $39 \%$, " rare" and "never" in $36 \%$ ) while $20 \%$ of Group D patients state frequent fears ("sometimes": $62 \%$, "rare" and "never": $14 \%$ ).

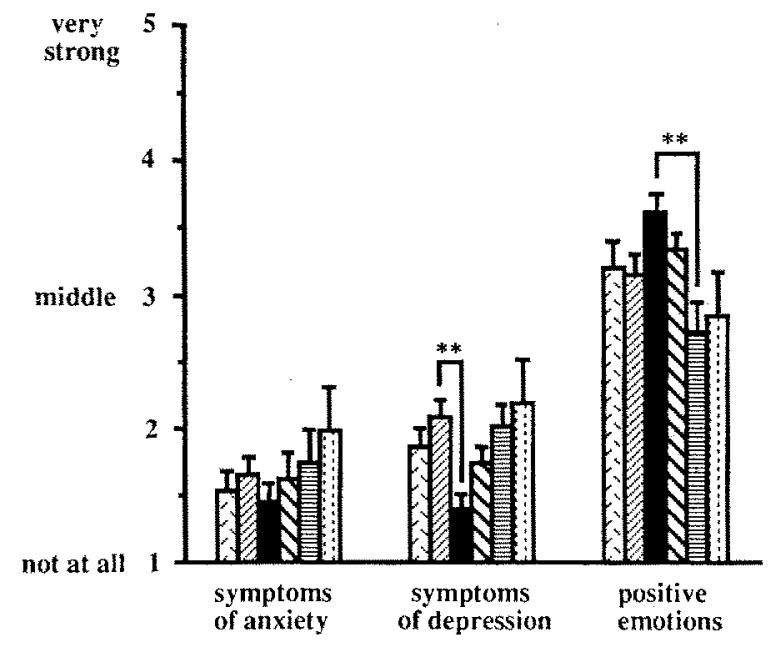

Fig.7. Mean scores of SCL-90-R subscales anxiety and depression and the positive emotions scale. For further details see legend to Figure $2 .{ }^{*} \mathrm{p}<0.05 ; * \mathrm{p}<0.01$

\section{Overall quality of life}

Group $C$ and $D$ both reported a much higher satisfaction with their present overall quality of life when compared to the other groups. The scores of Group $\mathrm{C}$ were significantly different $(p<0.01)$ from $A, B$ and $E$; those of $D$ were significantly different $(p<0.01)$ from $B$ and $E$ (Fig.8). The distribution of the five possible answers to the question in each group (Fig.9) showed that $74 \%$ of all patients in C and $69 \%$ in D were "satisfied" or "very satisfied" with their overall quality of life, whereas $65 \%$ in $\mathrm{A}, 61 \%$ in $\mathrm{B}, 60 \%$ in $\mathrm{E}$ and $66 \%$ in $\mathrm{F}$ answered "dissatisfied" or "neither-nor". 


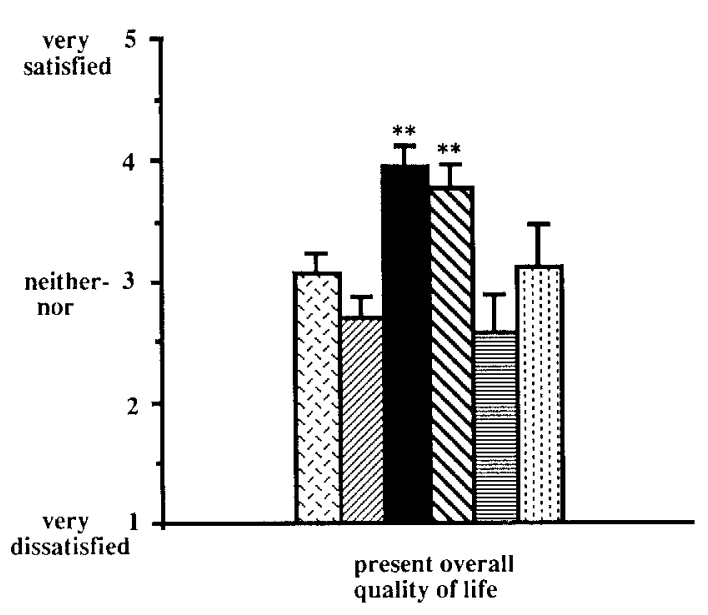

Fig.8. Mean scores of satisfaction with the present overall quality of life. For further details see legend to Figure 2.

${ }^{*} \mathrm{p}<0.05 ;{ }^{* *} \mathrm{p}<0.01$

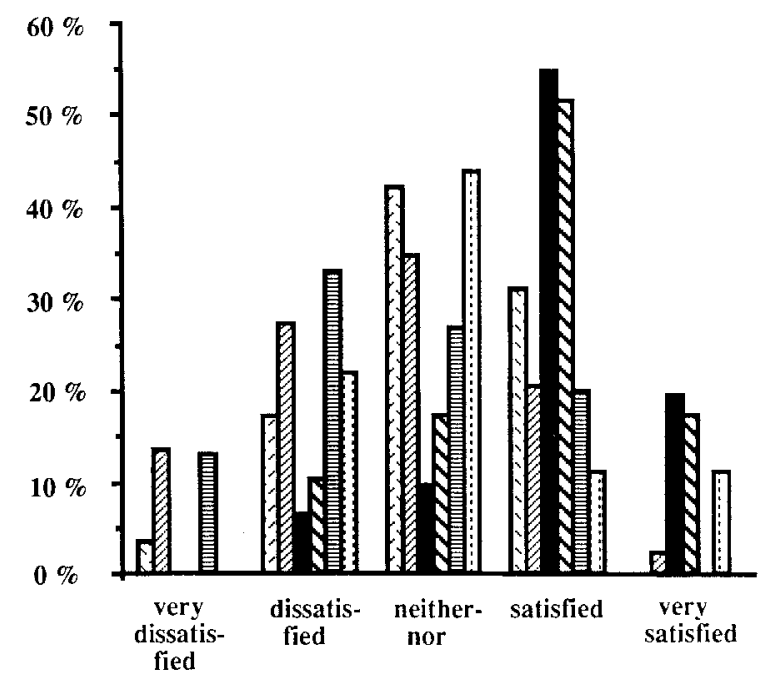

Fig.9. Distribution of answers concerning satisfaction with the overall quality of life. For further details see legend to Figure 2 .

\section{Relationships between overall quality of life and sub- components}

The highest Spearman correlation coefficients between the overall quality of life and different aspects are listed in Table 7. There was no significant correlation with age, sex, duration of diabetes, place and way of living (alone or with others).

In a further step multiple linear regression was used to evaluate the most important factors influencing the overall quality of life. The nine items were included as predictors, which showed high Spearman correlation coefficients when correlated to the overall quality of life: physical capacity $(r=0.69)$, leisure time activities $(r=0.64)$, positive emotions $(r=0.63)$, coping with treatment $(r=0.60)$, sexual activities $(r=0.53)$, vocational situation $(r=0.49)$, family life $(r=0.49)$, number of friends $(r=0.45)$ and financial situation $(r=0.34)$. The multiple linear regression yielded a $\mathrm{R}$-square of 0.70 . This means that the overall quality of life is described rather well by these nine items, which reflect the six main components of the basic concept (Fig.1).

Table 7. Spearman correlation coefficients between the present overall quality of life and different components of quality of life. Each $\mathrm{p}<0.01$

Aspects of quality of life Correlation coefficient (r)

\begin{tabular}{lc}
\hline Physical capacity & 0.70 \\
Coping with treatment & 0.63 \\
Positive emotions & 0.62 \\
Leisure time activities & 0.61 \\
Sexual activities & 0.54 \\
Vocational situation & 0.52 \\
Depression symptoms & -0.48 \\
Family life & 0.47 \\
Number of friends & 0.43 \\
Financial situation & 0.39 \\
Partner relationship & 0.36 \\
Mental capacity & 0.34 \\
\hline
\end{tabular}

\section{Discussion}

The present study investigated the quality of life of diabetic patients with regard to the benefits of a combined pancreas and kidney transplantation.

Results showed that both post-transplant groups with functioning pancreas and kidney or a kidney only rated their quality of life higher than the pre-transplant groups before or under dialysis and the post-transplant groups after complete rejection of both organs. This was observed not only in the overall rating but also in quality of life components, especially depression, leisure-time activities, physical capacity and sexual activities.

Poor results however were found with respect to vocational situation. Similar results have been reported in a multicentre study in Germany with non-diabetic kidney transplant recipients (Muthny et al. 1990). Of all posttransplant patients with a functioning kidney only $38 \%$ are working. Better results were obtained in other countries. The percentages of working patients posttransplant were $65 \%$ after combined pancreas-kidney grafting or $68 \%$ after kidney transplantation, both in diabetics (Nakache et al. 1989) and $74 \%$ in non-diabetic subjects after renal transplantation (Evans et al. 1985). The reasons for this difference are not clear and cannot be attributed to our health care and social system since in Sweden with a comparable socio-economic structure the vocational situation after grafting is much better (Nakache et al. 1989).

The data suggest that successful pancreas and/or kidney transplantation is associated with an improved quality of life (Evans et al. 1985; Nakache et al. 1989; Vorugati \& Sells 1989; Corry \& Zehr 1990; Johnson et al. 1990). An additional functioning pancreas leads to an even better quality of life when compared to kidney recipients only, although these further improvements are not seen in all aspects of quality of life. Similar results have been reported recently (Nakache et al. 1989; Corry \& Zehr 
1990). Positive effects of transplantation have been published also in heart transplant patients (Bullinger et al. 1991; Kemkes in press), non-diabetic renal transplant recipients (Kaplan De-Nour \& Muthny et al. 1990) and bone marrow recipients (Andrykowski 1987).

Even though such results are promising with regard to the benefits of transplantation, they are based on crosssectional studies, which suffer from potential sample/ selection biases and time/generation effects. Further research should make use of prospective designs which in spite of randomization problems will provide a more appropriate account of the changes in quality of life due to transplantation.

Quality of life assessment, however, seems to be an important outcome criterion for this type of intervention. The possibility to obtain the patient's account of his/her situation not only in physical, but also in social, emotional and functional aspects greatly enhances the medical evaluation potential. While various quality of life instruments have been carefully developed and used in different patient populations (e.g. Derogatis 1975; WoodDauphinee \& Williams 1987), their benefit in transplantation research and specifically in diabetic patients is rare. This is at least in part due to lack of knowledge about the instruments, their unavailability in a certain language and also the uncertainty as to how disease- and treatment-specific a tool should be. The questionnaire used in this study follows the diseasespecific approach (DCCT Research Group 1988). It does not represent a standard tool, but by including questions of special relevance to the patient group, it might add to the pool of information about the therapeutic alternatives in this disease. The development of a specific complaint list in this study represents a step toward a disease-specific and standardized assessment.

Finally the present study supports a multidimensional conceptualization of quality of life. Although global assessments are useful, subtle differences between treatments can only be distinguished using subscales, which assess relevant components of the quality of life concept.

With this strategy, the evaluation of outcomes can be fine-tuned so that a careful weighing of advantages and disadvantages of grafting becomes transparent and open for discussion. This has implications not only for clinical evaluation research but also for health political aspects of organ transplantation.

Acknowledgments. We thank Professors F. A. Muthny and U. Koch, Institute for Rehabilitation Psychology, University of Freiburg, for allowing us to modify their questionnaire and providing methodical information. We also wish to acknowledge the support of Mrs. Beranek, Department of Intemal Medicine "Innenstadt", for helping in the statistical evaluation and Mrs. Haag for the illustrations.

\section{References}

Aaronson NC (1989) Quality of life assessment in clinical trials: methodologic issues. Contr Clin Trials 10: 195S - 208S

Andrykowsky MA, Henslee PJ, Farall MG (1987) Physical and psychological functioning of adult survivors of allogenic bone marrow transplantation. Bone Marrow Transpl 4: 153 - 157
Bremer BA, McCauley CR (1986) Quality-of-life measures: hospital interview versus home questionnaire. Health Psychology 5(2): $171-177$

Bullinger M (1989) Concepts and methods of quality of life assessment. In: Fülgraff GM, Franke H, Lenau H, Rohde $\mathrm{H}$ (eds). Clinical pharmacology - current state and future aspects. CRF Press, Freiburg, pp $73-92$

Bullinger M, Angermann C, Zellner M, Spes C, Kemkes M (1991) Lebensqualität nach Herztransplantation. In: Bullinger $M$, Ludwig $M$, Steinbüchel $N$. Lebensqualität bei kardiovaskulären Erkrankungen. Hogrefe und Huber, Göttingen, pp $153-163$

Bullinger M. Quality of life - methodologist's view. Theoretical Surgery, in press.

Corry RJ, Zehr P (1990) Quality of life in diabetic recipients of kidney transplants is better with the addition of the pancreas. Clin. Transplantation 4: 238-241

DCCT Reaearch Group (1988) Reliability and validity of a diabetes quality-of-life measure for the Diabetes Control and

Complications Trial. Diabetes Care 11: 725-732

Derogatis LR (1975) Psychosocial adjustment to illness scale. Clinical Psychosomatic Research. Baltimore.

Evans RW, Manninen DL, Garrison LP, Hart LG, Blazz CR, Gutman RA, Hull AR, Lowrie EG, (1985) The quality of life of patients with end-stage renal disease. N Engl I Med 312: 553-559

Guyatt GH, Bombardier C, Tugwell PX (1986) Measuring diseasespecific quality of life in clinical trials. Can Med Ass J 134: 889 895

Han LG, Evans RW (1987) The functional status of ESRD patients as measured by the sickness impact profile. J Chron Dis 40 , Suppl 1 , $117 \mathrm{~S}-130 \mathrm{~S}$

Johnson JL, Schellberg J, Munn SR, Perkins JD (1990) Does pancreas transplantation really improve the patient's quality of life? Transplantation Proceedings 22: 575-576

Kaplan De-Nour A, Shanan J (1980) The quality of life of dialysis and transplanted patients. Nephron 25: 117-120

Kemkes BM. Quality of life issues in heart transplantation. Theoretical Surgery, in press.

Koostra G. Quality of life issues in renal surgery. Theoretical Surgery, in press

Leighton R, Quinn RJ, Hoefer MA (1987) Measuring overall health: an evaluation of three important approaches. J Chron Dis 40 , Suppl 1, 7S-21S

McDowell I, Newell C (1987) Measuring Health: A guide to rating scales and questionnaires. Oxford University Press, New York.

Muthny FA, Broda M, Dinger A, Koch U, Stein B (1990) Aspekte der Lebensqualität bei verschiedenen Behandlungsverfahren der chronischen Niereninsuffizienz - ein empirischer Vergleich. Blutreinigungsverfahren, ed. Franz H, Thieme, Stuttgart, pp 205-210

Najman JM, Levine S (1981) Evaluating the impact of medical care and technologies on the quality of life: review and a critique. Social Science in Medicine 15: 107-115

Nakache R, Tyden G, Groth CG (1989) Quality of life in diabetic patients after combined pancreas-kidney or kidney transplantation. Diabetes 38: 40-42

Neugebauer E, Wood-Dauphinee S, Troidl H, Eypasch E, Bullinger M. Quality of life assessment in surgery - consensus results of the Meran Conference. Theoretical Surgery, in press.

O'Young I, McPeek B (1987) Quality of life variables in surgical trials. J Chron Dis 40: $513-522$

Patrick DL, Erickson P (1988) Assessing health-related quality of life for clinical decision making. In: Walker SR, Rosser RM (eds) Quality of life: assessment and application. MTP Press, Lancaster, pp $183-197$

Troidl H, Kusche J, Vestweber KH, Eypasch E, Koeppen L, Boullon B (1987) Quality of life: an important endpoint both in surgical practice and research. J Chron Dis 40; 523 - 528

Vorugati LNP, Sells RA (1989) Quality of life of diabetic patients after combined pancreatic-renal transplantation. Clin Transplantation 3: 78-82

Walker SR, Rosser RM (1988) Quality of life assessment and application. MTP Press, Lancaster

Wood-Dauphinee $S_{2}$ Troidl H (1986) Endpoints for clinical studies: Conventional and innovative variables. In: Troidl $\mathrm{H}$, Spitzer WO, McPeek B, Mulder DS, McKneally MF (eds.) Principles and 
W. Piehlmeier et al.: Quality of life prior to and after pancreas and kidney transplantation

practice of research strategies for surgical investigators. Springer, New York, pp 53-68

Wood-Dauphinee S, Williams JI (1987) Reintegration to normal living as a proxy to quality of life. J Chron Dis 40:491- 499

Wood-Dauphinee S, Troidl $H$ (1989) Assessing quality of life in surgical studies. Theor Surg 4: 35 - 44

Dr. W. Piehlmeier

Professor R. Landgraf

Klinikum Innnenstadt

Medizinische Klinik

University of Munich

Ziemssenstr. 1

8000 Munich 2

FRG 